\title{
Board Acitivity and Firm Performance: Astudy of Financial Institutions in Kenya
}

\author{
Dr. Nebert Ombajo Mandala (PhD, CPAK, CPSK, CISA) \\ University of Nairobi, Kenya
}

Doi:10.19044/esj.2019.v15n1p282～ＵRL:http://dx.doi.org/10.19044/esj.2019.v15n1p282

\begin{abstract}
The research set out to determine whether board activity impacts institutional performance. Secondary data for a ten-year period between 2006 to 2015 from 98 sampled institutions from the financial sector was collected and analysed. The study adopted stratified sampling to ensure that all the categories of financial institutions were included in the sample. Analysis of the data was done by multiple regression analysis and generalized estimating equations. The study was anchored on several theories among them; the agency theory, stakeholder theory, and resource dependence theory. The findings are that board activity operationalised as the number of board meetings, significantly affect institutional performance. Additionally, the results further show that there exists an optimal number of board of director meetings with a statistical significant impact on institutional performance. 11 to 15 board of directors' meetings annualy were found to optimize institutional performance. The research findings will aid in managerial policy formulation and managerial practice that promote better governance practices hence leading to enhanced institutional performance.
\end{abstract}

Keywords: Board Activity, Board Meetings and Institutional Performance

\subsection{Introduction}

The modern business environment is characterized by uncertainty, risk and dynamism, making it harder to forecast and manage factors, which are more likely to impact institutional performance (Sanda, Mikailu \& Garba, 2005). This research paper proposes that adoption of good corporate governance practices is among the most viable options of improving institutional performance, and mitigating uncertainty and risk in a modern corporate environment. Moreover, it increases the possibility of getting additional investment capital due to reduced risk levels. Adoption of good corporate governance systems were necessitated by the agency conflicts which have become an integral part of the modern-day corporation, and increased 
owner emphasis on short-term performance and return outcomes (Sanda et al., 2005).

Corporate scandals in Kenya experienced by firms such as: Imperial Bank, Chase Bank, Dubai Bank, Uchumi Ltd, Mumias Sugar Company Ltd, CMC Ltd and East Africa Portland Ltd and outside Kenya such as Enron, WorldCom and HIH, questions the ability of the board of directors (BoDs) in executing its monitoring role. Geneen (1984) found out that $95 \%$ of the BoD of some 500 fortune companies, were not complying with legal requirements as expected of them. Geneen (1984) argues that the BoD is a puppet of management because of CEO dominance. They also concluded that the board is beleaguered with a lot of conflicts of interests' issues. Furthermore, interests of a controlling shareholder greatly influence the Board's decisions (Jesover \& Krikpatrick, 2005). Hence the primary question of monitoring the board: who will monitor the monitors? The BoD and by extension how the board is structured consequently, is likely to be an important driver of institutional performance. A number of studies argue that shareholders monitor the BoD by exercising their ownership right to elect or dismiss members of BoDs. However, shareholders are not necessarily aware of the firm's routine internal activities.

Researchers report mixed and contradictory results about the optimal board structure (Dalton et al., 1998). However, there appears to be agreement on the important variables representing board structure and that may have an impact on the monitoring and thus performance. The debate about influence of board structure on the performance of institutions continues, given that prior research has yielded conflicting results (Dalton et al., 1998) suggesting that other factors mediate or intervene to the acceleration of the relationship. Dalton et al. (1998) identifies ownership concentration as one of the factors that are likely to mediate or intervene in the relationship. Additionally, firm characteristics and CEO tenure could be some of the factors that come into play. A number of studies have established negative relationship among the CEO turnover, CEO tenure, and firms' performance (Murphy \& Zimmerman, 1993; Weisbach, 1988).

Five key characteristics of board structure have received attention in several studies, these variables include, board size, board composition, board diversity, CEO duality and number of board meetings. Most researchers agree with the conclusion that board structure variables are exogenously determined (Eisenberg et.al., 1998), Yermack, 1996; and Jensen, 1993). Some of the notable studies include that of Mak and Kusnadi (2002) who concluded that the smaller the board size, the higher the institutional value. Baysinger and Butler (1985), Mehran (1995), and Klein (1998) on the other hand, show that institutional performance was not significantly associated with a higher proportion of non-executive directors on the board. Vafeas (1999) as well as 
Adams and Ferreira (2004) were of the view that frequent board meetings contributed to improved institutional performance. Wah et al. (2015) found that board diversity as measured by the number of female members of the BoD has a significant positive influence on institutional performance. Prior studies on CEO duality found mixed evidence. Yermack (1996) argued that performance is optimized when CEO duality exists, while Daily and Dalton (1992) report absence of association between CEO duality and institutional performance. A number of studies both theoretical and empirical agree that board structure variables differ in relation to the institutional characteristics (Boone, et al., 2005; Adams, 2005; Baker \& Gompers, 2003; Lehn et. al., 2003; and Hartzell \& Starks 2003,). Hermalin and Weisbach (2003) were of the view that there is empirical review on the determinants of an optimal structure of the board or the factors that influence an optimal board size is scanty.

These findings lead to the conclusion that empirical studies conceptualized along the influence of either board structure or board activity on institutional performance in developing countries are rare. Prior research on various corporate governance variables has been within the context of developed countries (e.g., Dahya and McConnell, 2007; Wintoki et al. 2012). Of importance is that a number of institutional factors regarding developing countries are quite different and hence, this research moves to a new setting, and reviews the influence board activity on institutional performance in a developing economy.

Prior empirical research on board structure and institutional performance have demonstrated that the relationship is quite equivocal and does not reveal any conclusive relationship (Dalton \& Daily, 1999). Board structure variables explored include size, diversity, CEO duality, busyness and independence among others. However, no evidence has been found that board activity as defined in this study has been used as a variable in the current context. The question remains as to the casual association among these variables.

\subsection{Research Objectives}

The objective of this research was to establish whether an association exists among board activity and performance of financial institutions in Kenya. It also sought to determine whether there exists an optimal number of the board meetings that would optimise performance.

\subsection{Empirical Review}

\subsection{Board Activity}

The BoD is the most significant corporate governance structure in all institutions (Lim, 2010). The way the board is characterised impacts the 
strategic decisions, including how resources are allocated and thus ultimately affect profitability (Mallin, 2010; OECD, 1999). In addition to providing strategic direction, the BoD also undertakes the major monitoring function which addresses the agency problem within the institution (Fama, 1980). However, the $\mathrm{BoD}$ is not the only remedy to all the governance problems within corporations in modern times (Ongore, 2011). To take cognizant of the corporate governance problems, institutions are required to further factor risktaking orientations of their equity holders who affect managerial decisions regarding investments (Shleifer \& Vishny, 1994).

Board activity maybe defined as the number and frequency of events and or meetings that require the engagement of the entire board of directors. Different approaches can be used to define this perspective. One considers the board meetings only while other approaches focus on all meetings and events that require the board members participation. Board process is characterized by decision-making activities among the board members of institutions.

Many empirical studies agree that directors' equity shares ownership increases institutional performance (Jensen \& Murphy, 1990; Chung \& Pruitt, 1996; Palia \& Lichtenberg, 1999). Brickley et al. (1988) were of the view that ownership of shares by the board leads to effective management of the firm and proper checks on managers. However, other researchers have not agreed about the relation between managers equity share ownership and institutional performance. De Angelo and De Angelo (1985) in agreement with the agency theory, stated that substantial equity share ownership by the management makes it more difficult to institute management changes hence resulting in agency conflict. Morck et al. (1988) and Shleifer and Vishny (1997) foresee the possibility of managers taking advantage of the corporate for their own benefit. Becht et al., (2005) from their study were of the view that CEO equity share ownership makes them take advantage of their positions to benefit financially at the expense of other equity holders. Other empirical studies have come to the conclusion that equity share ownership by management is endogenic (Demsetz \& Lehn, 1985; Loderer \& Martin, 1997; Cho, 1998).

Various studies about the size of the board have produced equivocal results (Johl. 2015; Kajola, 2008; Barako et al., 2006). Most studies debating, from several viewpoints, do not agree on the board size (Jensen 1993). A number of empirical studies are in support of small board size arguing that this enhances the institutional performance (e.g., Lipton \& Lorsch, 1992; Jensen 1993; Yermack, 1996) however, others support the notion that big boards are more ideal because they positively impact on performance (Pfeffer, 1972; Klein, 1998; Coles et al., 2008). Lipton and Lorsch (1992) were in support of smaller boards arguing that they would help the institution to avoid social loafing and free-riding. Jensen (1993) added that smaller boards usually eased co-ordination, cohesiveness and communication. This matches O'Reilly et al. 
(1989) view, which declared that with the increase in board size, the effectiveness of interpersonal communication decreases, and coordination problems seem to be obvious, which would most probably develop factions and conflicts. Furthermore, earlier studies; Yermack (1996) and Eisenberg et al. (1998) concluded that small boards resulted in increased firm performance.

Larger boards were deemed efficient because of its association with proper monitoring of the management activities and advisory role to the CEO (Adam \& Mehran, 2003; Klein, 1998; Pfeffer, 1972). Klein (1998) concluded that complexity of an institution enhances the CEO's need for guidance from the board. It is worth noting that the agency theory is in support of larger boards for their monitoring effectiveness which emanates from reducing the CEO's hold on the board and protecting the equity holders from exploitation (Singh \& Harianto, 1989).

Various researchers have attempted to explain the contradictory relationship among board structure variables and institutional performance. Nonetheless, the performance level attributed to a given board structure has not been clearly established (Johnson, Daily \& Ellstrand, 1996). Dalton and Daily (1999) concluded that several decades of empirical review aimed at establishing the association among board structure and institutional performance have been inconclusive.

\subsection{Institutional Performance}

Firm performance is an imperative idea that describes the means and ways through which organizational resources are employed to achieve corporate strategy. It keeps the organization a float and brings about better vision for future opportunities (Hoskisson et al., 1994). Performance of the firm relates to its efficiency, effectiveness, financial viability and relevance. Effectiveness brings out the peculiar abilities which organizations must embrace in ensuring attainment of their missions. Efficiency is described as the unit cost of output which is much less than the input leaving no alternative option through which the input can be reduced for the same amount of output (Machuki \& Aosa, 2011). Financial viability on the other hand has been defined as a firm's ability to harness its financial resources which are its inflow of financial resources that must be greater than the outflow. Relevance is the ability of a firm to develop in ways that consolidate their strengths. Ricardo et al. (2001) defines performance as the ability of a firm to maximize strengths to overcome its weaknesses to neutralize its threats and take advantages of opportunities.

Performance measurement is characterized by measurement difficulties. While the study has zeroed in on performance, some scholars have expressed concern that the field has yielded inconclusive results, often drawing "seemingly conflicting findings" regarding the determinants of 
performance. Awino (2011) concludes that no single variable can effectively influence a firm's performance. Performance measures are many and varied with some schools of thought advocating for financial performance measures and others for the non-financial performance measures. Not a single measure of performance can completely explain all aspects of the term due to organizational objectives and contextual factors (Snow \& Hambrick, 1980). This may be partly because definition of performance incorporates efficiencyrelated measures, relating to the input/output models and effectiveness related measures, dealing with issues such as growth, employee satisfaction, commitment, and turnover (Mayer \& Schoorman, 1992; Machuki \& Aosa, 2011). Sometimes, performance is conceptually confused with productivity. Productivity is defined as a ratio which depicts the volume of work completed within a defined period of time. Performance is therefore broader, and productivity is one of its indicators (Ricardo, 2001).

Firm performance usually represents the quality of the firm's on-going relationship with the environment. It can be represented by growth, profitability, and other non-financial indicators. Firm performance depends on the context and incorporates indicators in multiple analysis levels (Kaplan \& Norton, 1992). While its description refers to a particular point in time, development, periodic change and varied time scales will need to be considered. Static efficiency may lead to instability in the long run and a temporary misfit could be required to attain long-term dynamic fit. Due to this, incompatible short-term and long-term alliances need to be sorted out in firm performance. It also needs to show how a firm is effectively exploiting available resources while generating new ones.

Firm performance may also be said to be a multi-dimensional construct (Chakravathy, 1986); which a single index may not necessarily be able to give a detailed understanding of relationship compared to the particular construct of interest. Different performance measures exist including both long-term and short-term market performance measures. Studies document several measures that have been used to varying extent including market value added (MVA), return on assets (ROA), economic value added (EVA), free cash flow enhancement, earnings per share (EPS) enhancement, asset enhancement, dividend enhancement, and revenue enhancement (Abdullah, 2004). For instance, Dehaene et al. (2001) adopted return on equity (ROE) and return on assets (ROA) as measures of firms' performance and concluded that this was effective in providing adequate performance information while Chen et al. (2005) suggested that market related measures were better and thus used the market-to-book ratio in their study of firms. Hong Kong. Judge et al. (2003) used several indicators which included both quantitative and qualitative measures such as profitability, customer satisfaction, product/service quality, capacity optimisation and business process enhancement in assessment of 
institutional performance. Firm performance remains a challenging concept both in terms of how it should be defined and measured because of its multifaceted and multidimensional nature. Most studies of firm performance posit that performance is a dependent variable and seek to identify variables that explain variation in terms of performance.

Ocasio, 1994 and Hoskisson et al., 1994 find that accounting-based financial measures, market-based measures including combinations of both have been relied upon in most studies which focus on the association among corporate governance and profitability of an institution. Accounting based performance indicators of the firm rely on accounting ratios that do not incorporate the stock market variables while measures that are based on market variables include the Tobins $\mathrm{Q}$ and return on the market which incorporate the stock price. Financial accounting measures despite having been criticized many times have been relied on by many studies. The criticism emanates from the fact that such measures (1) can aid in creative accounting through, manipulating accounting information; (2) may likely devalue assets; (3) generate biases as a result of accounting policies and methods adopted by the firm; and (4) lack standardization in financial reporting as some jurisdictions have not adopted international financial reporting standards. Also, interpretation of financial accounting statements and ratios is subjective in case of cross cutting industry participation by the various firms (Nayyar, 1992) or where the firm's ownership structures are varied.

In contrast, market-based measures have several benefits. Risk adjusted performance measurement is reflected in these indicators; they are not negatively impacted upon by cross cutting industry or multinational contexts (Nayyar, 1992). Deckop, 1987 concludes that the main reason for this is that market-based performance indicators are in control of external forces and not within the management's control. Literature does not document any consensus concerning the efficacy of dependence on either accounting-based indicators or market-based indicators, many studies have resorted to using a mix of the financial performance measures.

\subsection{Methodology}

\subsection{Research Design, Data and Sampling}

The study was a descriptive correlational survey. Using data from a developing country, Kenya, the research sought to determine the relationship between board activity and institutional performance. The data was collected for a ten-year period from 2006 to 2015 for the institutions that were sampled from the financial sector in Kenya, through data collection sheets from annual reports and company websites. The population comprised of all financial institutions in Kenya being 3989 institutions. This composed of five regulators, 43 commercial banks, 10 Investment banks, two development 
banks and one mortgage finance company, 41 insurance companies, nine deposit taking micro-finance institutions, and 3,887 Sacco's (http://www.centralbank.go.ke). The study followed the simple stratified random sampling in obtaining viable set of data sets and sampled 98 firms from all the categories. The data collected composed of the number of meetings and or events requiring the board participation held by each of the sampled institution annually.

\subsection{Data Analysis}

The data collected was prepared, coded, analysed, organized and used to report the findings as well as results of tests of hypotheses. In getting the data ready for analysis, data editing, standardization, coding and categorization was undertaken. Descriptive statistics which included measures of central tendency were computed. Standard deviation was adopted to explore dispersion in the collected data. In addition, coefficient of variation, kurtosis and skewness were also computed, for confirming normality of the data. All the variables of the research were described, and the salient characteristics of the data collected provided, this enabled the researcher to conduct further data analyses (Mugenda \& Mugenda, 2003).

Moderated and stepwise regression models and correlation analysis were used to determine the relationship between board activity and institutional performance using ROA and Sales growth. A number of variables were denoted in logarithm form since they were measured in millions while others were denoted as percentages where the values were also high and the remaining as absolute numbers. The usage of logarithm was to enhance standardization of values in the model.

Multiple regression analysis was used in analysis of the collected data. Parametric and non-parametric methodologies were used. Tests of goodness of fit including the adjusted coefficient of determination $\left(\overrightarrow{R^{2}}\right)$, t-tests, standard error of estimate (Se) and ANOVA were also done. The regression was performed in the form of a panel; several panel regression options, fixed effects, random effects, OLS, generalized squares (GLS), and panel that is dynamic were performed. Because OLS makes no use of the information contained in the unequal variability exhibited by the predictor and to ensure that the analysis produces the best linear estimators GLS has also been used. The General Estimation Equation (GEE) procedure has been used to extend the generalized linear model (GLM) to allow for repeat measurements. This allowed analysis of the variables of the study over the ten-year period in the research. 


\subsection{Results}

\subsection{Descriptive Statistics}

Performance of financial institutions in Kenya was the dependent variable of this study. The indicators of performance were ROA and Revenue Growth Rate. These performance indicators had been used for similar studies by Yammeesri and Lodh (2004), Johl et.al. (2015), Yammeesri et al. (2006), Rashid and Lodh (2008). ROA was computed as the Earnings before Interest and Taxes (EBIT) divided by the book value of total assets. In Table 4.1 below are the descriptive statistics.

The maximum ROA for the financial institutions sampled was 24.9, 25.99 and 21.38 for Banks, Insurance and Saccos respectively (see Table 4.6). Commercial banks exhibit the largest asset base, compared to the other categories of financial institutions, but when it comes to performance (ROA), it is ranked second. The minimum ROA was -15.55, 3.84 and 8.48 for Banks, Insurance and Saccos respectively; while the average ROA from Banks, Insurances and Saccos were 3.20, 6.83 and 2.64 respectively. Half the ROA for Banks, Insurance and Saccos are less than or equal to 3.20, 6.07 and 1.72 respectively whereas their respective ranges in ROA are 40.45, 29.83 and 29.85. From skewness, the study observed that the average scores of all the firm performance constructs are positively skewed and is very near to zero, which clarified that the constructs are asymmetrical. Kurtosis values indicated that all the sub constructs have platy-kurtic distribution, and it is concluded that they are normally distributed.

Descriptive statistics was also carried out for growth in revenue being the other firm performance measure. The results show that the maximum and minimum number of growth in revenue for Banks, Insurances and Saccos are $35.99,56.65$ and 47.52 and $-6.14,-23.56$ and -20.90 respectively. The average growth in sales for Banks, Insurance and Saccos are 14.19, 19.12 and 16.52 respectively, whereas their corresponding medians are 13.50, 17.32 and 15.33 indicating that the means are not very far from their respective medians implying that they follow a normal distribution and thus allowed for correlation and regression analysis to be undertaken. Additionally, growth in EBIT was analyzed and the results in table 4.6 above show that, the maximum and minimum number of Growth of EBIT in Banks, Insurances and Saccos are $40.78,38.90,53.43$ and $-14.37,-9.83,-11$ respectively. The results also indicate that the respective means and medians are 14.26, 13.13 and 19.25 for Banks, Insurances and Saccos respectively. 
Table 4.1: Descriptive Statistics for Firm Performance

\begin{tabular}{|c|c|c|c|c|c|c|c|c|c|c|c|c|c|c|}
\hline & & \multirow[t]{2}{*}{ Mean } & \multicolumn{2}{|c|}{$\begin{array}{r}5 \% \text { Confidence } \\
\text { Interval }\end{array}$} & \multirow{2}{*}{\begin{tabular}{|r|}
$5 \%$ \\
Trimmed \\
Mean
\end{tabular}} & \multirow[t]{2}{*}{ Median } & \multirow[t]{2}{*}{ Variance } & \multirow[t]{2}{*}{ d. Deviation } & \multirow[t]{2}{*}{ Minimum } & \multirow[t]{2}{*}{ Maximum } & \multirow[t]{2}{*}{ Range } & \multirow[t]{2}{*}{$\begin{array}{r}\text { Interquartile } \\
\text { Range }\end{array}$} & \multirow[t]{2}{*}{ Skewness } & \multirow[t]{2}{*}{ Kurtosis } \\
\hline & & & \begin{tabular}{|l|} 
Lower \\
Bound
\end{tabular} & $\begin{array}{l}\text { Upper } \\
\text { Bound }\end{array}$ & & & & & & & & & & \\
\hline \multirow{2}{*}{$\begin{array}{l}\text { ROA } \\
\text { Bank }\end{array}$} & Statistic & 3.205 & 2.809 & 3.600 & 3.145 & 3.207 & 10.443 & 3.231 & -15.548 & 24.908 & 40.456 & 2.8622 & 1.419 & 20.264 \\
\hline & Std. Error & 0.200 & & & & & & & & & & & & \\
\hline \multirow{2}{*}{$\begin{array}{r}\mathrm{ROA} \\
\text { Insurance }\end{array}$} & Statistic & 6.831 & 6.238 & 7.424 & 6.588 & 6.075 & 21.726 & 4.661 & -3.838 & 25.990 & 29.829 & 5.9428 & 0.928 & 1.649 \\
\hline & Std. Error & 0.300 & & & & & & & & & & & 0.157 & 0.313 \\
\hline \multirow{2}{*}{$\begin{array}{r}\text { ROA } \\
\text { Sacco } \\
\end{array}$} & Statistic & 2.637 & 2.291 & 2.984 & 2.328 & 1.719 & 8.995 & 2.999 & -8.479 & 21.3785 & 29.8582 & 2.3137 & 2.086 & 8.973 \\
\hline & Std. Error & 0.176 & & & & & & & & & & & 0.143 & 0.285 \\
\hline \multirow{2}{*}{$\begin{array}{r}\text { Growth of } \\
\text { EBIT }\end{array}$} & Statistic & 16.610 & 15.633 & 17.587 & 16.677 & 16.515 & 195.496 & 13.981 & -14.571 & 53.4332 & 68.0050 & 18.8570 & -0.046 & -0.338 \\
\hline & Std. Error & 0.497 & & & & & & & & & & & 0.087 & 0.174 \\
\hline \multirow{2}{*}{$\begin{array}{r}\text { Growth of } \\
\text { Sales } \\
\end{array}$} & Statistic & 16.548 & 15.518 & 17.578 & 16.751 & 15.684 & 217.219 & 14.738 & -23.556 & 56.6533 & 80.2098 & 80.2098 & -0.055 & 0.661 \\
\hline & Std. Error & 0.524 & & & & & & & & & & & 0.087 & 0.174 \\
\hline
\end{tabular}

\begin{tabular}{|c|c|c|c|c|c|c|c|c|c|c|c|c|c|c|c|}
\hline & & & Mean & 5\% Con & $\begin{array}{l}\text { fidence } \\
\text { nterval }\end{array}$ & $\begin{array}{r}5 \% \\
\text { Trimmed } \\
\text { Mean }\end{array}$ & Median & Variance & td. Deviation & Minimum & Maximum & Range & $\begin{array}{r}\text { Interquartile } \\
\text { Range }\end{array}$ & Skewness & Kurtosis \\
\hline & & & & $\begin{array}{l}\text { Lower } \\
\text { Bound }\end{array}$ & $\begin{array}{l}\text { Upper } \\
\text { Bound }\end{array}$ & & & & & & & & & & \\
\hline \multirow{6}{*}{$\begin{array}{r}\text { Growth of } \\
\text { EBIT }\end{array}$} & \multirow[t]{2}{*}{ Bank } & Statistic & 14.89 & 13.02 & 16.76 & 15.096 & 14.259 & 233.541 & 15.282 & -14.5718 & 40.7802 & 55.3520 & 25.2134 & -0.155 & -1.104 \\
\hline & & Std. Error & 0.949 & & & & & & & & & & & 0.151 & 0.302 \\
\hline & \multirow[t]{2}{*}{ Insurance } & Statistic & 14.89 & 13.24 & 16.55 & 14.885 & 13.132 & 169.166 & 13.006 & -9.8314 & 38.8980 & 48.7294 & 17.0886 & 0.196 & -0.526 \\
\hline & & Std. Error & 0.839 & & & & & & & & & & & 0.157 & 0.313 \\
\hline & \multirow[t]{2}{*}{ Sacco } & Statistic & 19.56 & 18.04 & 21.07 & 19.612 & 19.252 & 170.856 & 13.071 & -11.0044 & 53.4332 & 64.4376 & 17.2052 & 0.027 & 0.809 \\
\hline & & Std. Error & 0.767 & & & & & & & & & & & 0.143 & 0.285 \\
\hline \multirow{6}{*}{$\begin{array}{r}\text { Growth of } \\
\text { Sales }\end{array}$} & \multirow[t]{2}{*}{ Bank } & Statistic & 14.19 & 12.84 & 15.53 & 14.069 & 13.495 & 121.568 & 11.025 & -6.1423 & 35.9907 & 42.1331 & 18.6541 & 0.292 & -0.890 \\
\hline & & Std. Error & 0.685 & & & & & & & & & & & 0.151 & 0.302 \\
\hline & \multirow[t]{2}{*}{ Insurance } & Statistic & 19.12 & 16.73 & 21.52 & 19.511 & 17.332 & 354.415 & 18.825 & -23.556 & 56.6533 & 80.2098 & 19.4190 & -0.391 & 0.146 \\
\hline & & Std. Error & 1.215 & & & & & & & & & & & 0.157 & 0.313 \\
\hline & \multirow[t]{2}{*}{ Sacco } & Statistic & 16.52 & 14.96 & 18.07 & 16.714 & 15.332 & 180.151 & 13.422 & -20.901 & 47.5165 & 68.4178 & 9.5513 & -0.072 & 1.013 \\
\hline & & Std. Error & 0.788 & & & & & & & & & & & 0.143 & 0.285 \\
\hline
\end{tabular}

Author, 2017 


\subsection{Generalized Estimating Equations}

The procedure for Generalized Estimating Equations (GEE) was applied in extending the Generalized Linear Model (GLM) to enable the researcher to analyze repeated data measurements. The GLM repeated data measures technique affords examination of variance in cases where similar measurements are done several times on each subject or case. For instance, ROA was measured for 10 years in this study. By adopting the general linear model technique, the study tested the hypotheses regarding influence of both the between-subjects elements and the within-subjects elements. These explored relationships among elements in addition to influence of individual elements. Furthermore, the influence of constant covariates and covariate interactions with the between-subjects elements were included. The GLM repeated measures technique enabled the researcher to determine the values of multiple dependent scale variables obtained at multiple time periods, based on their association to categorical and scale independent variables and the time periods at which they were obtained. This section presents the result of how ROA depend on gender diversity of boards and board composition using the GEE procedure. The model information table 1 below summarizes the section on modelling selection to ensure that the procedure fits the appropriate model.

Table 1: Model Information

\begin{tabular}{|c|c|c|}
\hline \multicolumn{2}{|c|}{ Dependent Variable } & Return on Assets \\
\hline \multicolumn{2}{|c|}{ Probability Distribution } & Normal \\
\hline \multicolumn{2}{|c|}{ Link Function } & Identity \\
\hline Subject Effect & 1 & Name \\
\hline Within-Subject Effect & 1 & Year \\
\hline \multicolumn{2}{|c|}{ Working Correlation Matrix Structure } & Unstructured \\
\hline
\end{tabular}

Author, 2017

The Normal Probability Distribution (NPD) is appropriate since return on total asset is a scale variable and its values take a symmetric, bell-shaped distribution about a central (mean) value. The link function is an alteration of the dependent variable that permits prediction of the model. The following link function which can also be used with any distribution is used - Identity, $\mathrm{f}(\mathrm{x})=$ $\mathrm{x}$. The dependent variable is not altered.

The name captures the names of the firms in this study, which are the main subjects of the study. The year captures the within subject data. The working correlation matrix is a representative of the within-subject dependencies. The size is indicated by the number of observations and thus the amalgamation of values of within-subject variables. There are five possible structures: Independent which assumes that repeated observations are uncorrelated; AR (1) in which it is assumed that repeated observations have a first-order autoregressive association and that the correlation among any two elements is equal to $\mathrm{r}$ for adjacent elements, $\mathrm{r}^{2}$ for elements that are separated 
by a third, and so on. $\mathrm{r}$ is constrained so that $-1<\mathrm{r}<1$; Exchangeable which assumed that the structure has homogenous correlations between elements, it is also known as a compound symmetry structure; M-dependent in which it is assumed that consecutive observations have a common correlation coefficient. Greater separation among observations leads to the assumption that they are uncorrelated; unstructured, which is a completely general correlation matrix (help ibm.spss.statistics, 2017). The Working Correlation Matrix Structure with the best result, based on the data in this study is unstructured. The other structure does not tell much. The results are presented in section 4.1, in summary the results indicate that board activity operationalized through the number of board meetings significantly affects firm performance.

\subsection{Board Activity and Institutional Performance}

The first objective of the research assessed the influence of board activity on Kenyan financial institution's performance. The research predicted that there was no significant influence of board activity on the institution's performance. Performance was measured through ROA and revenue growth for each institution. To assess if the board activity variable (NBMeet/BA) did not significantly predict ROA and Revenue growth of financial institutions in Kenya, the researcher applied hierarchical multiple regression analysis. This was the test of the first hypothesis and the sub hypotheses as shown below:

Ho1: There is no significant effect of board activity on performance of financial institutions in Kenya.

The prediction equations is as shown below; $\mathrm{ROA}_{i, \mathrm{t}}=\alpha+\beta{ }_{1} \mathrm{BA}_{\mathrm{i}, \mathrm{t}}+\varepsilon_{\mathrm{i}, \mathrm{t}}$. and $\mathrm{RGR}_{\mathrm{i}, \mathrm{t}}=\alpha+\beta{ }_{1} \mathrm{BA}_{\mathrm{i}, \mathrm{t}}+\varepsilon \mathrm{i}, \mathrm{t}$.

The GEE results for firm performance and board activity operationalized through ROA and the categories of the number of board meetings (NBMeet or BA) and other activities respectively are presented in table 4.2 to 4.6 below. The number of board meetings operationalised as NBMeet was categorised in four classes ( 0 to 3 ) as per table 4.2 which also presents the percentages of firms that held that particular number of meetings per category.

Table 4.2: Categorical Variable Information

\begin{tabular}{|c|c|c|c|c|}
\hline & & & $\mathrm{N}$ & Percent \\
\hline \multirow{5}{*}{ Factor } & \multirow{5}{*}{$\begin{array}{c}\text { Categories Of Number of } \\
\text { Board meetings and other } \\
\text { activities }\end{array}$} & 1 to 6 Meetings in a & 420 & $53.2 \%$ \\
\hline & & $\begin{array}{c}7 \text { to } 10 \text { Meetings in a } \\
\text { Year }\end{array}$ & 60 & $7.6 \%$ \\
\hline & & $\begin{array}{c}11 \text { to } 15 \text { Board Meetings } \\
\text { in a Year }\end{array}$ & 121 & $15.3 \%$ \\
\hline & & $\begin{array}{c}16 \text { to } 27 \text { Meetings in a } \\
\text { Year }\end{array}$ & 189 & $23.9 \%$ \\
\hline & & Total & 790 & $100.0 \%$ \\
\hline
\end{tabular}


Table 4.3: Goodness of Fit ${ }_{a}$

\begin{tabular}{|c|c|}
\hline & Value \\
\hline Quasi Likelihood under Independence Model Criterion (QIC) $)^{\mathrm{b}}$ & 17849.223 \\
\hline $\begin{array}{c}\text { Corrected Quasi Likelihood under Independence Model Criterion } \\
(\text { QICC) }\end{array}$ & 17781.282 \\
\hline
\end{tabular}

Dependent Variable: Return on Total Assets a. Information criteria are in small-is-better form.

Model: (Intercept), NBMeetCla likelihood function

b. Computed using the full log quasi-

Table 4.4: Tests of Model Effects \& Parameter Estimates

\begin{tabular}{|c|c|c|c|c|c|c|c|}
\hline \multirow[t]{2}{*}{ Source } & \multicolumn{3}{|c|}{ Type III } & & & & \\
\hline & $\begin{array}{c}\text { Wald Chi- } \\
\text { Square }\end{array}$ & df & \multicolumn{2}{|l|}{ Sig. } & & & \\
\hline (Intercept) & 64.355 & 1 & \multirow{2}{*}{\multicolumn{2}{|c|}{$\begin{array}{l}.000 \\
.000\end{array}$}} & & & \\
\hline NBMeetCla & 26.457 & 3 & & & & & \\
\hline \multirow[t]{2}{*}{ Parameter } & \multirow[t]{2}{*}{ B } & \multirow[t]{2}{*}{$\begin{array}{l}\text { Std. } \\
\text { Error }\end{array}$} & \multicolumn{2}{|c|}{$\begin{array}{l}95 \% \text { Wald } \\
\text { Confidence } \\
\text { Interval }\end{array}$} & \multicolumn{2}{|c|}{ Hypothesis Test } & \\
\hline & & & Lower & Upper & $\begin{array}{c}\text { Wald Chi- } \\
\text { Square }\end{array}$ & Df & Sig. \\
\hline (Intercept) & -.855 & .9830 & -2.782 & 1.072 & .756 & 1 & .384 \\
\hline [NBMeetCla $=0$ & 5.264 & 1.1244 & 3.060 & 7.468 & 21.917 & 1 & .000 \\
\hline$[$ NBMeetCla $=1$ & 4.765 & 1.2014 & 2.411 & 7.120 & 15.735 & 1 & .000 \\
\hline$[\mathrm{NBMeetCla}=2$ & 7.908 & 1.8054 & 4.370 & 11.447 & 19.186 & 1 & .000 \\
\hline$[\mathrm{NBMeetCla}=3$ & & & & & & & \\
\hline (Scale) & & & & & & & \\
\hline
\end{tabular}

Dependent Variable: Return on Total Assets

Model: (Intercept), NBMeetCla a. Set to zero because this parameter is redundant.

Table 4.5: Estimated Marginal Means

\begin{tabular}{|c|c|c|c|c|}
\hline \multirow[t]{2}{*}{$\begin{array}{l}\text { Categories Of Number of board } \\
\text { meetings and other activities }\end{array}$} & \multirow[t]{2}{*}{ Mean } & \multirow[t]{2}{*}{ Std. Error } & \multicolumn{2}{|c|}{$\begin{array}{l}\text { 95\% Wald Confidence } \\
\text { Interval }\end{array}$} \\
\hline & & & Lower & Upper \\
\hline 1 to 6 Meetings in a Year & 4.409169 & .5458838 & 3.339256 & 5.479081 \\
\hline 7 to 10 Meetings in a Year & 3.910531 & .6905976 & 2.556984 & 5.264077 \\
\hline 11 to 15 Board Meetings in a Year & 7.053296 & 1.3833166 & 4.342046 & 9.764547 \\
\hline 16 to 27 Meetings in a Year & -.854926 & .9830387 & -2.781647 & 1.071794 \\
\hline
\end{tabular}


Table 4.6: Working Correlation Matrix

\begin{tabular}{|c|c|c|c|c|c|c|c|c|c|c|}
\hline \multirow[b]{2}{*}{ Measurement } & \multicolumn{10}{|c|}{ Measurement } \\
\hline & $\begin{array}{c}{[} \\
\text { Year } \\
= \\
2006 \\
]\end{array}$ & $\begin{array}{c}{[} \\
\text { Year } \\
= \\
2007 \\
]\end{array}$ & $\begin{array}{c}{[} \\
\text { Year } \\
= \\
2008 \\
]\end{array}$ & $\begin{array}{c}{[} \\
\text { Year } \\
= \\
2009 \\
]\end{array}$ & $\begin{array}{c}{[} \\
\text { Year } \\
= \\
2010 \\
]\end{array}$ & $\begin{array}{c}{[} \\
\text { Year } \\
= \\
2011]\end{array}$ & $\begin{array}{c}{[} \\
\text { Year } \\
= \\
2012 \\
]\end{array}$ & $\begin{array}{c}{[} \\
\text { Year } \\
= \\
2013 \\
]\end{array}$ & $\begin{array}{c}{[} \\
\text { Year } \\
= \\
2014 \\
]\end{array}$ & $\begin{array}{c}{[} \\
\text { Year } \\
= \\
2015]\end{array}$ \\
\hline [ Year $=2006$ & 1.000 & .916 & .916 & .796 & .674 & .437 & .517 & .484 & .501 & .482 \\
\hline [ Year $=2007$ & .916 & 1.000 & .916 & .835 & .744 & .526 & .585 & .667 & .604 & .566 \\
\hline$[$ Year $=2008$ & .916 & .916 & 1.000 & .848 & .668 & .504 & .544 & .670 & .526 & .541 \\
\hline $\begin{array}{c}{[\text { Year }=2009} \\
]\end{array}$ & .796 & .835 & .848 & 1.000 & .652 & .451 & .569 & .702 & .551 & .560 \\
\hline$\left[\begin{array}{c}\text { Year }=2010 \\
]\end{array}\right.$ & .674 & .744 & .668 & .652 & 1.000 & .511 & .623 & .684 & .524 & .534 \\
\hline $\begin{array}{c}{[\text { Year }=2011} \\
]\end{array}$ & .437 & .526 & .504 & .451 & .511 & 1.000 & .553 & .566 & .436 & .443 \\
\hline$[$ Year $=2012]$ & .517 & .585 & .544 & .569 & .623 & .553 & 1.000 & .732 & .556 & .582 \\
\hline$[$ Year $=2013]$ & .484 & .667 & .670 & .702 & .684 & .566 & .732 & 1.000 & .722 & .819 \\
\hline$[$ Year $=2014]$ & .501 & .604 & .526 & .551 & .524 & .436 & .556 & .722 & 1.000 & .624 \\
\hline$[$ Year $=2015]$ & 482 & .566 & .541 & .560 & .534 & 443 & .582 & .819 & 624 & 1.000 \\
\hline
\end{tabular}

Dependent Variable: Return on Total Assets

Model: (Intercept), NBMeetCla

Author, 2017

In Table 4.2 are the results for the four categories of board activity, measured in terms of board meeting. The categories of board meetings were as follows: firms that held 1 to 6 board meeting a year (53.2\%), firm that held 7 to 10 board meetings a year ( $7.6 \%$ ), firm that held 11 to 15 board meetings a year $(15.3 \%)$ and firm that held 16 to 27 board meetings a year (23.9\%). The data in Table 4.3 shows that the unstructured correlation structure provides a better model and therefore, is used throughout this section. The results in Table 4.4 showed the reference category for the number of board meetings is $\mathrm{NBMeetCla}=3$; that is, firms with 16 to 27 board meetings in a year; and the value of 7.908 for NBMeetCla=2 means that, all other things being equal, we would expect the ROA of firms with 11 to 15 board meetings to be 7.908 higher than firms categorized as $\mathrm{NBMeetCla}=3$; and the value of 4.765 for NBMeetCla $=1$ means that, all other things being equal, we would expect the ROA of firms with 7 to 10 board meetings to be 4.765 higher than firms categorized as NBMeetCla $=0$. The relationships are statistically significant indicating that board activity influences firm performance. Overall the findings provide evidence that there is an optimal number of board meetings that firm performance is optimized. Table 4.5 shows that the mean ROA is highest for firms with 11 to 15 board meetings in a year with mean ROA of $7.05 \%$, for 7 to 10 meetings, the mean is $3.9 \%, 1$ to 6 meetings are $4.4 \%$ and for 16 to 27 
meetings the mean ROA is $-0.85 \%$ indicating that very high meetings negatively impact performance. This means that board activity is a predictor of performance as measured by ROA. Table 4.6 indicate that there is no information in the history as years 2006 and 2015 have very low correlation, the correlation decreases as the gap for the years increase.

The study hypothesized that board activity does not significantly affect institutional performance. The findings from hierarchical multiple regressions provide evidence that there is a significant effect of board activity on institutional performance. The findings also provide evidence that 11 to 15 board of directors' meetings annualy optimize institutional performance.

\subsection{Conclusion \& Recommendations}

Three data analysis methods were applied on the data collected to achieve the research objectives. The data analysis methods used included correlation analysis, generalized estimating equations (GEE) and variants of regression analysis. The result provided by the three data analysis methods was to confirm the influence of board activity on performance of financial institutions in Kenya;

The findings agree with the agency theory and the convergence-ofinterests theory. The study findings additionally indicate that there is an optimal number of board of director meetings that have a statistically significant influence on institutional performance. 11 to 15 board of directors' meetings annualy were found to optimize institutional performance. In support of the convergence-of-interests theory board activity, particularly because of equity ownership is found to significantly impact institutional performance. This finding could be attributed to the fact that agency conflict can be resolved by encouraging management share options so as to align the interest of employees and directors with those of the equity holders; and the convergence-of-interests theory, which postulates that when board of directors had no equity ownership, they are self-oriented, but they have little power to circumvent firm controls that have been developed to align their decision making for the benefit of the residual owners. This was consistent with extant literature; however, whose results have been mixed, vexing and contradictory. Jointly, the individual contribution of each board structure variable had a significant influence on performance.

Prevoius research has postulated that corporate governance is critical to institutional performance. Board activity has also been associated with institutional performance. Nonetheless, scanty empirical review is available on the impact of board activity on institutional performance in emerging economies. This research sought to determine this association. The research findings will arouse deeper academic discourse on the association of these variables; form a basis for developing policy 
as well as managerial practice in performance of institutions in Kenya and beyond.

\section{References:}

1. Abdullah, S. (2004). Board Composition, CEO Duality and Performance among Malaysian Listed Companies. Corporate Governance, 4 (4), 47-61.

2. Adam, R. B., \& Mehran, H. (2003). Is Corporate Governance Different for Bank Holding Companies? Economic Policy Review - Federal Reserve Bank of New York, 9(1), 123-142.

3. Adams, R., \& Ferreira, D. (2009). Women in the boardroom and their impact on governance and performance. Journal of Financial Economics, 94(2): 291-309.

4. Adams, Rene B. \& Ferreira (2004). The moderating effect of group decision making, working paper, Stockholm School of Economics.

5. Adams, Rene B. (2005). What do boards do? Evidence from committee meeting and director compensation data, Working Paper, Federal Reserve Bank of New York.

6. Awino, Z.B. (2011). Strategic management: An empirical investigation of selected strategy variables on Firm' performance: A study of supply chain management in large private manufacturing firms in Kenya. Prime Journals, 1(1), 9-18.

7. Baker, Malcolm, and Gompers, P.A. (2003). The determinants of board structure at the initial public offering. Journal of Law and Economics, 46, 569-598.

8. Barako, D.G., Hancock, P., \& Izan, H. Y. (2006). Factors influencing voluntary corporate disclosure by Kenyan companies. Journal compilation, Blackwell Publishing Ltd, 14, 121-148.

9. Baysinger, B. D. \& Butler H. (1985). CG and the Board of Directors: Performance Effects of Changes in Board Composition. Journal of Law, Economics and Organization 1, 650-657.

10. Baysinger, B. D., Kosnik, R.D. \& Turk, T.A. (1991). Effects of board and ownership structure on corporate R\&D strategy. Academy of Management Journal, 34, 205-214.

11. Becht, M., Bolton, P., \& Roell, A. (2005). Corporate Governance and Control. European Corporate Governance Institute. ECGI Working Paper Series in Finance No. 02/2002, Updated August 2005.

12. Boone, Audra, Laura C. Field, Jonathan Karpoff, and Charu G. Raheja (2005). The determinants of board size and composition: an empirical analysis. Journal of Financial Economics, forthcoming. 
13. Brickley, J. A., Lease, R. C. and Smith, C. W. (1988) Ownership Structure and Voting on Antitakeover Amendments, Journal of Financial Economics, 20, 267-292.

14. Chakravathy, B.S. (1986). Measuring Strategic Performance. Strategic Management Journal, 7(5): 437-458.

15. Chen, Z., Cheung, Y., Stouraitis, A. \& Wong, A. W. S. (2005). Ownership Concentration, Firm Performance, and Dividend Policy in Hong Kong. Pacific-Basin Finance Journal, 13(4), 431-449.

16. Cho, M. H. (1998). Ownership structure, investment and the corporate value: An empirical analysis. Journal of Financial Economics, 47,103121.

17. Chung, K. H., \& Pruitt, S. W. (1996). Executive Ownership, Corporate Value and Executive Compensation: A Unifying Framework. Journal of Banking and Finance. 20(7), 1135-1159.

18. Coles, J.L., N.D. Daniel, \& L. Naveen (2008). Boards: Does One Size Fit All? Journal of Financial Economics 87, 329-356.

19. Dahya, J. and McConnell, J. J. (2007). Board Composition, Corporate Performance, and the Cadbury Committee Recommendation. Journal of Financial and Quantitative Analysis, 42(3), 535-564.

20. Dalton, D. R.; Daily, C. M.; Ellstrand, E.A. \& Johnson, J. L. (1998). Meta-Analytic Review of Board Composition, Leadership Structure and Financial Performance. Strategic Management Journal, 19 (3), 269-290.

21. Dalton, D., \& Daily, C. (1999). What's wrong with having friends on the board? Across the Board, (March), 28-32.

22. DeAngelo, H., DeAngelo, L., (1985). Managerial ownership of voting rights: A study of public corporations with dual classes of common stock. Journal of Financial Economics 14, 33-69.

23. Deckop, J. (1987). Top executive compensation and the pay-forperformance issue. In D. B. Balkin and L. R. Gomez-Mejia (eds.), New Perspectives in Compensation. Prentice Hall, Englewood Cliffs, NJ, 285-293.

24. Dehaene, A, De Vuyst, V \& Ooghe, H 2001, 'Corporate Performance and Board Structure in Belgian Companies', Long Range Planning, vol. 34, no. 3, pp. 383-98.

25. Demsetz H., Lehn K. (1985). The structure of corporate ownership: Causes and consequences. Journal of Political Economy, 93(6), 11551177.

26. Eisenberg, T., Sundgren, S. and Wells, M.T. (1998). Larger board size and decreasing firm value in small firms. Journal of Financial Economics, Vol. 48 No. 1, pp. 35-54. 
27. Fama, Eugene F. (1980). Agency Problems and the Theory of the Firm. Journal of Political Economy 88, no. 2 (April): 288-307.

28. Geneen, H. (1984), Why Directors Can't Protect Shareholders? Fortune, 110 (6): 28-32.

29. Hartzell, Jay and Laura Starks (2003). Institutional investors and executive compensation, Journal of Finance 58, 2351-2374.

30. Hermalin, B. E. and Weisbach M. S. (2003). Board of Directors as an Endogenously Determined Institution: A Survey of the Economic Literature, Economic Policy Review, 9 (1): 7-26.

31. Hoskisson, R. E., Johnson, R. A. \& Moesel, D.D. (1994). Corporate divestiture intensity in restructuring firms: Effects of governance, strategy, and performance. Academy of Management Journal, 37, 1207-1251.

32. Jensen, M. C. (1993). The Modern Industrial Revolution Exit and the Failure of Internal Control Systems. The Journal of Finance, 48 (3): 831-880.

33. Jensen, M.C. and Murphy, K. J. (1990). CEO incentives-it's not how much you pay, but how. Harvard business review, (3), 138 -153.

34. Jesover, F. and G. Krikpatrick (2005). The Revised OECD Principles of Corporate Governance and their Relevance to the Non-OECD Countries, Corporate Governance: An International Review, 13 (2): 127-136.

35. Johl S.K, Kaur S., \& Cooper B. J. (2015). Board Characteristics and Firm Performance: Evidence from Malaysian Public Listed Firms, Journal of Economics, Business and Management. Vol. 3, No. 2.

36. Johnson, J., Daily, C., \& Ellstrand, A. (1996). Boards of directors: A review and research agenda. Journal of Management, 22, 409-438.

37. Judge, W. Q., Naoumova, I. \& Koutzevol, N. (2003), Corporate Governance and Firm Performance in Russia: An Empirical Study. Journal of World Business, 38 (4): 385-396.

38. Kajola Sunday (2008). Corporate Governance and Firm Performance: The Case of Nigerian Listed Firms. European Journal of Economics, Finance and Administrative Sciences ISSN 1450-2275 Issue 14.

39. Kaplan, R. S, \& Norton, D.P. (1992). The balanced scorecard-measures that drive performance. Harvard Business Review, Jan-Feb, 719.

40. Klein, A. (1998). Firm Performance and Board Committee Structure. Journal of Law and Economics, 41(1), 275-30.

41. Lehn, Kenneth, Sukesh Patro, and Mengxin Zhao (2003). Determinants of the size and structure of corporate boards: 1935-2000, Working Paper, University of Pittsburgh.

42. Lim, S.C. (2010). A study in corporate governance, strategic and tactical regulation. Washington: World Business Council for 
Sustainable Development OECD (1999), Corporate Governance; Effects on Firm Performance and Economic Growth. Paris: OECD.

43. Lipton, M. \& Lorsch, J.W. (1992). A modest proposal for improved corporate governance. Business Lawyer, 48(1) 59-77.

44. Loderer, C., \& Martin, K. (1997). Executive Stock Ownership and Performance: Tracking Faint Traces. Journal of Financial Economics, 45(2), 223-255.

45. Machuki, V.N., \& Aosa, E. (2011). The influence of the external environment on performance of publicly quoted companies in Kenya. Prime Journal of Business Administration and Management, 1(7), 205-218.

46. Mak, Yuen Teen, and Yuanto Kusnadi (2002). Size really matters: further evidence on the negative relationship between board size and firm value, Pacific-Basin Finance Journal, 13, 301-318.

47. Mallin, C.A. (2010). Corporate governance, 3rd Edition, New York: Oxford University Press Inc.

48. Mayer, R. C., \& Schoorman, F. D. (1992). Differentiating antecedents of organizational commitment: a test of March and Simon's model. Journal of Organizational Behavior, 19, 15-28.

49. Mehran, H. (1995). Executive compensation structure, ownership, and firm performance Journal of Financial Economics, 38 (2): 163-184.

50. Morck, R., Shleifer, A. \& Vishny, R.W. (1988). Management Ownership and Market Valuation: An Empirical Analysis. Journal of Financial Economics, 20, 293-315.

51. Mugenda, O.M. and Mugenda, A.G. (2003). Research methods: Quantitative and Qualitative approaches. Nairobi: ACTS Press.

52. Murphy, Kevin J., \& Jerold L. Zimmerman (1993). Financial performance surrounding CEO turnover. Journal of Accounting and Economics, 16, 1-3, 273-315.

53. Nayyar, P. R. (1992). Performance effects of three foci in service firms. Academy of Management Journal, 35, 985-1009.

54. Ocasio, W. (1994). Political dynamics and the circulation of power: CEO succession in U.S. industrial corporations, 1960-1990. Administrative Science Quarterly, 39, pp. 285-312.

55. Ongore, V. O., K'Obonyo, P. O., Ogutu, M., \& Bosire, E. M. (2015). Board Composition and Financial Performance: Empirical Analysis of Companies Listed at the Nairobi Securities Exchange. International Journal of Economics and Finance. Issues, 5(4), 23-43.

56. Ongore, V.O., \& K Keebonyo, P.O. (2011). Effects of selected CG characteristics on firm performance: Empirical evidence from Kenya. International Journal of Economics and Financial Issues, 1 (3), 99122. 
57. Palia, D., \& Lichtenberg, F. (1999). Managerial Ownership and Firm Performance: A Re-examination Using Productivity Measurement. Journal of Corporate Finance, 5(4), 323-339.

58. Pfeffer, J. (1972). Size and Composition of Corporate Boards of Directors: The Organization and its Environment. Administrative Science Quarterly, 17, 2, 218228.

59. Pfeffer, J., \& Salancik, G. (1978). The external Control of Organizations: A Resource-Dependence Perspective.

60. Ricardo, R., \& Wade, D. (2001). Corporate performance management: how to build a better organization through measurement driven strategies alignment. Butterworth, Heinemann.

61. Sanda, A., A. Mikailu, \& T. Garba. (2005). Corporate governance mechanisms and firm financial performance in Nigeria. African Economic Research Consortium (pp. 47). Sokoto.

62. Shleifer, A., \& Vishny, R.W. (1994). A survey of corporate governance. Journal of Finance, 52(2), 737-783.

63. Singh, H., \& Harianto, F. (1989). Management-Board Relations, Takeover Risk, and the Adoption of Golden Parachutes. Academy of Management Journal, 32(1), 7-24.

64. Singh, V., Terjesen, S., \& Vinnicombe, S. (2008) Newly appointed directors in the Boardroom: How do women and men differ? European Management Journal, 26(1), 48-58

65. Snow, C. C. \& Hambrick, D. C. (1980). Measuring organizational strategies: some theoretical and methodological problems. Academy of Management Review, 5, 527-538.

66. Vafeas, N. (1999). Board Meeting Frequency and Firm Performance. Journal of Financial Economics, 53(1), 113-142.

67. Wah Khaw K., Shafie M. Z., Kamilah Ahmadb (2015). Corporate Governance Practices and Firm Performance: Evidence from Top 100 Public Listed Companies in Malaysia. 7th International Economics \& Business Management Conference, 5th \& 6th October 2015.

68. Weisbach, M. (1988). Outside directors and CEO turnover. Journal of Financial Economics, 20, 431-460.

69. Wintoki, M. B., Linck, J. S. \& Netter, J. M. (2012). Endogeneity and the Dynamics of Internal Corporate Governance. Journal of Financial Economics, 105(3), 581-606.

70. Yermack, D. (1996). Higher Market Valuation of Companies with a Small Board of Directors. Journal of Financial Economics 40, 185 211. 